\title{
The Return Of Hong Kong To China: An Analysis
}

Pete Mavrokordatos, Tarrant County College, USA; University of Phoenix, USA; Intercollege Larnaca, Cyprus Stan Stascinsky, Tarrant County College, USA

\begin{abstract}
The purpose of this paper is to discuss a topic that is somewhat recent, with outcomes that are still uncertain and hard to predict. The topic is the return of Hong Kong to China on July 1, 1997. It has only been 15 years since that date, and the impact is not completely clear yet. What the authors are aiming to do is to collect enough data from the literature, to be able to do an evaluation of both of these economies, before and after 1997. In attempting to do this an extensive discussion of both of the economies will be done, and it will be supplemented by the two GDPs, the Growth Rates and any other figures that might be relevant for this purpose.
\end{abstract}

Keywords: Hong Kong; China; Economic Growth

\section{INTRODUCTION/HISTORICAL ANALYSIS}

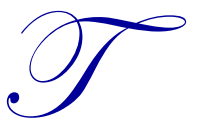

he goal of the authors in this section is to discuss and compare the economies of both China and Hong Kong, from a historical point of view, since one the recent economic development in the world, which everyone is looking at with reservations, is the return of Hong Kong to China during the summer of 1997. In doing this historical overview, an extensive research was done in the literature, and the results will be presented in the following pages. The results of the return of Hong Kong to China will be presented for the last 15 years. It is true though, and it is generally accepted and expected that this deal will have some side effects on the world economy, but whether these side effects will be good or bad no one can predict.

Through the historical analysis, and later with a statistical analysis, one will be able to see where these two countries have been, and where they are headed, and based on this information an attempt can be made to forecast the future of China and Hong Kong united and of the impact on the rest of the world.

\section{China}

The Chinese have always viewed their country as a unified state with a strong central government led by a single ruler, that controlled the subordinate weaker local governments and neighboring states, this does not mean that China did not have its ups and downs. Over the last several hundred years a lot of developments took place and the following are some of the most important ones. In 1911, we have the army revolution that ended the Empire and begun the Republic. Then in 1921 we see the formation of the Communist Party (CCP). Another important development took place in 1949, when Mao Zedong signed the Sino-Soviet Alliance in Moscow, and then in 1950 we have the land reform. In 1966, we see the beginning of the best years of Mao's ruling and the start of the Cultural Revolution. In more recent years, and specifically 1979, the United States established diplomatic relations with China, but the economic reforms did not start until 1980, at which time China admitted to the IMF. The most recent event, the return of Hong Kong to China, was signed by the British and the Chinese in 1984. Finally, the last two major developments that took place in China were the opening of the Shanghai Stock exchange in 1991, and the first free elections that took place in 1992.

As mentioned above, after the establishment of the People's Republic, the first thing that took place was the land reform, under the guidance of the government. At that time 700 million acres were confiscated and distributed to 300 million landless peasants. During that time, and as a result of that, there was some growth and development, 
but collectivization was necessary. Another important development in the Chinese economy was the co-operative movement, which contributed to a lot of changes in the overall economy. Between 1951 and 1953, the government organized the peasants into mutual aid teams which were made up by a dozen households, and by 1956 more than $96 \%$ of all the peasant households belonged to some agricultural producer's cooperatives. By 1958 the government developed a more effective organization, and that was the creation of the Communes in the Rural Areas.

The next development dealt with the industry. Before 1949, the industry played a very small role in the Chinese economy, but after the liberation and by 1956 everything was transformed from private to public or collective ownership. This contributed to the development of large and medium sized industrial projects, since it turned out to be a major stimulus to the development of the productive forces. The final outcome of this transformation is that by 1978 , industry made up $74 \%$ of the GNP, whereas prior to 1949 was only $30 \%$. Two more important aspects of the Chinese economy that need to be discussed at this point deal with "money and banking" and "commerce", and they are important, since the whole economy depends heavily on these two for its development. The money and banking system is run by the state, and the state budget is the master scheme of all public finances, and it is made up by the budgets of both the central and the local governments. The revenues come from state enterprises, industrial and commercial taxes, salt tax, customs tariffs, and agricultural taxes among others. On the other hand, the state expenditures are outlays on economic development, cultural affairs, education, science, public health, national defense and administration.

The other important aspect is commerce, which is controlled by the Ministry of Commerce. By the time the Republic was formed, in 1949, tariffs were reinstated and trade was put under the control of the Central government, and it has been steadily growing since then. The Chinese exports are: agricultural products, subsidiary products, light industrial products and manufactured and mineral products. On the other hand $80 \%$ of the imports are means of production and advanced technology and equipment.

\section{Hong Kong}

The other country that this paper focuses on is Hong Kong. Hong Kong has also gone through some developments over the years, and the purpose of this section is to go over some of the most important developments.

Hong Kong was formed as a result of three Treaties between Great Britain and the Qing Dynasty of China. The three Treaties were:

a. The Treaty of Nanjing which was signed in 1842, at the conclusion of the First Opium War, at which the Chinese government gave Hong Kong to Great Britain.

b. The First Convention of Beijing. This took place in 1860 after the Arrow War, at which time China gave to Britain more territory, such as the Stonecutter's Island, and the Peninsula of Kowloon.

c. The Second Convention of Beijing, that took place in 1898, at which the New Territories were given to Britain as well.

Even after these three Treaties, this British Colony had a very slow start, and it only picked up after the founding of the People's Republic of China in 1949, at which time a lot of Chinese fled to Hong Kong, which now is around six million. During the last 40 years, a lot of other things took place in Hong Kong, which contributed to making Hong Kong what it is today. With respect to trade, in 1950, Hong Kong became a free port, and that obviously offered a lot of advantages to other countries. Also at the same time, Hong Kong became China's economic window to the outside world, which means that everything that goes in and out of China has to go through Hong Kong. In the 60s, we see the beginning of industrialization, and the switching from the low end consumer goods into appliances and electronics. This did not last very long, since in the 70 s they had rising labor and real estate costs that forced them to move from manufacturing to money and banking. On the other hand, and more recently, when China started opening to the West, Hong Kong shifted back to manufacturing, but even though the plants and factories were owned by Hong Kong residents, they were located across the border in the Guangdong Province, where the cost of production is much lower. As a result of all the ongoing reforms in China, Hong Kong residents started investing there heavily, and by 1989 more than 2000 factories were operating across the border, in the Guangdong, and they all created more than a million jobs in Southern China. 
Hong Kong has been so successful over the years because of a number of things, but two of them deserve most of the credit:

a. the free flow of information

b. adherence to the rule of law

But even though Hong Kong is a success story, it still has its own problems, such as serious environmental pollution and high crime rates, among others.

\section{STATISTICAL ANALYSIS}

The goal of the authors in this section is to compare the two economies, that of Hong Kong and that of China, as two separate economies at first, and then both of them together since 1997. In order to do the comparison, several sets of data will be used from each country: The Gross Domestic Product (GDP), $(2000=100)$ the Growth Rates, and the Net Exports, all in US dollars for the years 1980 to 2010 will be presented. These are the most important indicators in providing a good picture of the direction of any economy. All figures will be presented both in a tabular form and graphically.

At this point though, and before these figures are shown and discussed, it is important to discuss briefly the two economies. Even though Hong Kong is a free market economy, with very few tariffs, natural resources are very limited and both food and raw materials must be imported. Also due to the fact that Hong Kong is a free zone area, exports of goods and services are more than 50\% of its GDP. Its per capita GDP is $\$ 35,537$ and the composition of GDP by sector is $0.2 \%$ agriculture, $18.4 \%$ industry and $81.4 \%$ services. The labor force is around 3.7 million, and the unemployment stands at about 3.6\% (2008) and 5.2\% (2009).

On the other hand the situation in China is a little different. In 1978, the Chinese leadership started moving the Chinese economy from a Soviet-style centrally planned economy to one that is more market oriented. As a result of this GDP has more than tripled since 1978. Even though their growth rates have been steadily rising, the per capita GDP is only $\$ 2425,(2000=100)$ and the composition of GDP by sector is the following: $19 \%$ agriculture, $48 \%$ industry, and only $33 \%$ services, and all three percentages give us a completely different picture than that of Hong Kong. The Chinese labor force is around 787 million and the unemployment rate is around $4.3 \%$, (2009) which is fairly high.

\section{THE COMPARISON}

In this section the purpose of the authors is to present several economic indicators for both of these countries, both before and after the return of Hong Kong to China. This data is shown in Table 1 below and Table 2 that follows. Through comparison this data will give us a good indication first what the situation was in both of these countries before they were united, and then the impact of the union. 
Table 1: Hong Kong and China Data 1980 - 2010

\begin{tabular}{|c|c|c|c|c|c|c|}
\hline & H. Kong & China & H. Kong & China & H. Kong & China \\
\hline YEAR & NET EXP. & NET EXP. & GDPBIL \$ & GDPBIL \$ & UNEMPL. & UNEMPL. \\
\hline & $\mathbf{X}-\mathbf{M}$ & $\mathbf{X}-\mathbf{M}$ & $2000=100$ & $2000=100$ & $\%$ & $\%$ \\
\hline 1980 & 1.8945 & 13.9006 & 60.1503 & 182.9411 & 3.7 & 4.9 \\
\hline 1981 & 2.2394 & 18.5514 & 65.7547 & 192.4541 & 3.5 & 3.8 \\
\hline 1982 & 2.5584 & 23.2966 & 67.675 & 209.9674 & 3.6 & 3.2 \\
\hline 1983 & 3.3881 & 18.5758 & 71.7124 & 232.8538 & 4.4 & 2.3 \\
\hline 1984 & 5.3919 & 15.2706 & 78.8282 & 268.2476 & 3.8 & 1.9 \\
\hline 1985 & 5.3505 & -5.1978 & 79.3577 & 304.461 & 3.2 & 1.8 \\
\hline 1986 & 6.5565 & -1.625 & 88.1646 & 331.2536 & 2.8 & 2 \\
\hline 1987 & 8.4939 & 8.5786 & 99.9884 & 369.679 & 1.7 & 2 \\
\hline 1988 & 8.5498 & 1.102 & 108.4321 & 411.4527 & 1.4 & 2 \\
\hline 1989 & 9.2213 & -0.6559 & 110.8416 & 428.3223 & 1.1 & 2.6 \\
\hline 1990 & 7.2647 & 14.7994 & 115.1628 & 444.5986 & 1.3 & 2.5 \\
\hline 1991 & 5.3431 & 14.4242 & 121.7208 & 485.5016 & 1.8 & 2.3 \\
\hline 1992 & 3.1539 & 4.3761 & 129.1373 & 554.4429 & 2 & 2.3 \\
\hline 1993 & 4.3045 & -10.4887 & 136.9413 & 632.0649 & 2 & 2.6 \\
\hline 1994 & -0.5958 & 5.2012 & 145.176 & 714.8654 & 1.9 & 2.8 \\
\hline 1995 & -4.4001 & 1.1436 & 148.5053 & 792.7857 & 3.2 & 2.9 \\
\hline 1996 & -2.3463 & -0.8633 & 154.732 & 872.0642 & 2.8 & 3 \\
\hline 1997 & -6.5664 & 15.7032 & 162.5556 & 953.1662 & 2.2 & 3.1 \\
\hline 1998 & -3.5318 & 13.0162 & 152.7594 & $1,027.51$ & 4.6 & 3.1 \\
\hline 1999 & 6.3966 & 10.9153 & 156.6639 & $1,105.60$ & 6.2 & 3.1 \\
\hline 2000 & 7.5166 & 28.8735 & 169.121 & $1,198.47$ & 4.9 & 3.1 \\
\hline 2001 & 6.6634 & 25.0873 & 169.9621 & $1,297.95$ & 5.1 & 3.6 \\
\hline 2002 & 10.9712 & 67.4016 & 173.091 & $1,416.06$ & 7.3 & 4 \\
\hline 2003 & 16.2445 & 74.2945 & 178.2942 & $1,557.67$ & 7.9 & 4.3 \\
\hline 2004 & 23.0497 & 83.5083 & 193.3896 & $1,714.99$ & 6.7 & 4.2 \\
\hline 2005 & 33.651 & 160.169 & 207.0857 & $1,908.79$ & 5.6 & 4.2 \\
\hline 2006 & 37.9653 & 247.9811 & 221.6227 & $2,151.20$ & 4.8 & 4.1 \\
\hline 2007 & 37.8182 & 340.4063 & 235.7829 & $2,456.67$ & 4 & 4 \\
\hline 2008 & 39.7905 & 407.6765 & 241.2208 & $2,692.51$ & 3.6 & 4 \\
\hline 2009 & 30.3449 & 240.1565 & 234.803 & $2,940.22$ & 5.2 & 4.3 \\
\hline 2010 & 33.6249 & 382.6355 & 251.169 & $3,246.01$ & 4.3 & 4.1 \\
\hline
\end{tabular}

Source: GDP (constant 2000 US\$); Exports of goods and services (constant 2000 US\$); Imports of goods and services (constant 2000 US\$); World Bank national accounts data, and OECD National Accounts data files; International Monetary Fund; International Financial Statistics and Balance of Payments databases; International Monetary Fund, International Financial Statistics and data files; Unemployment, total (\% of total labor force); International Labour Organization, key Indicators of the Labour Market database 


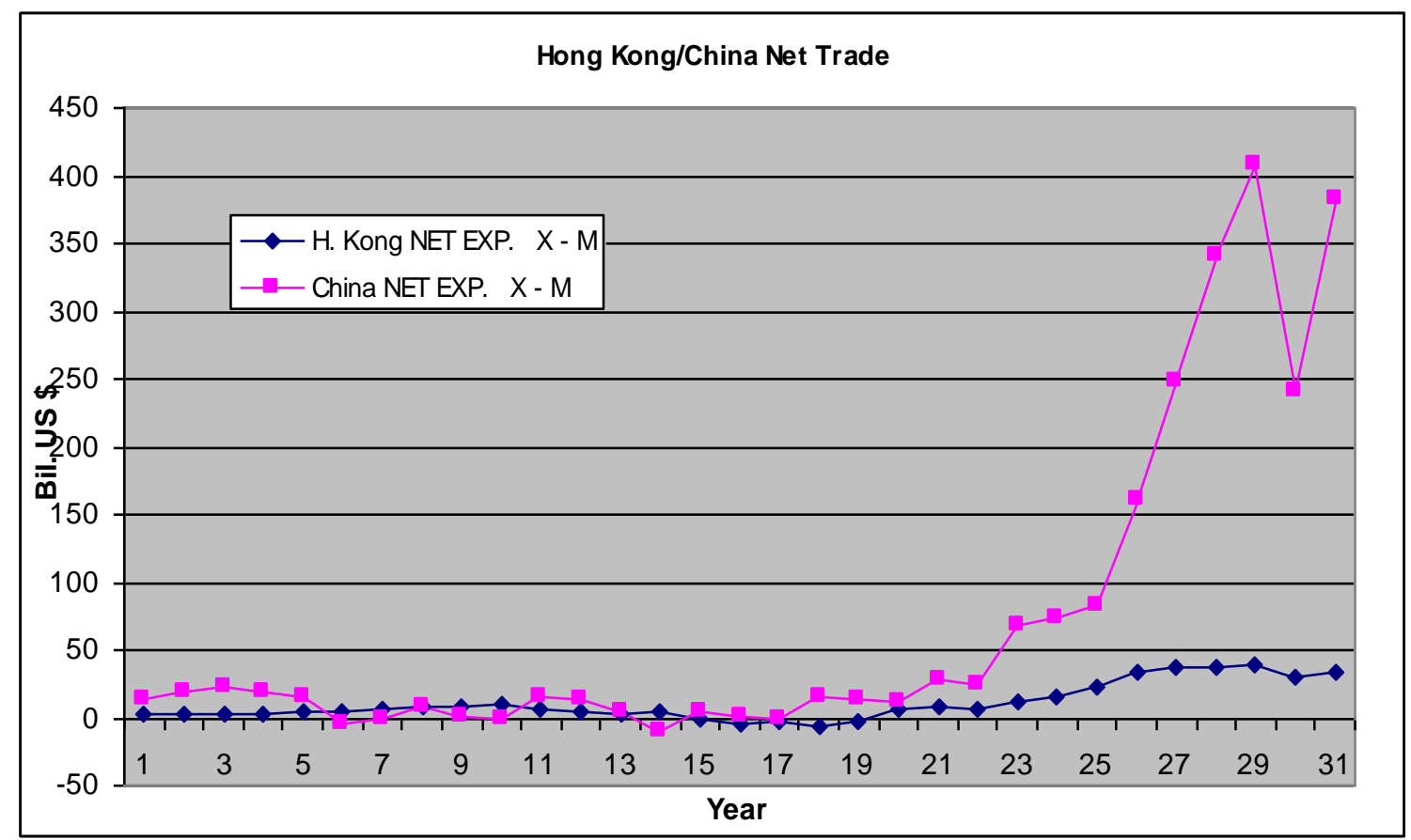

Figure 1

Figure 1 above shows the net trade of both countries. As can be seen, before 1997 their net trade was pretty much even, and in fact both countries had negative trade for several years. After 1997 though the trade has increased for both countries, to the point that net exports for Hong Kong went from a negative 3.5 bill. to 33.6 bill. and for China it went from 15.7 bill. to 382.6 bill. in 2010, even though in 2008 it was 407.6 bill. This shows that these two countries have a lot of things that the rest of the world wants.

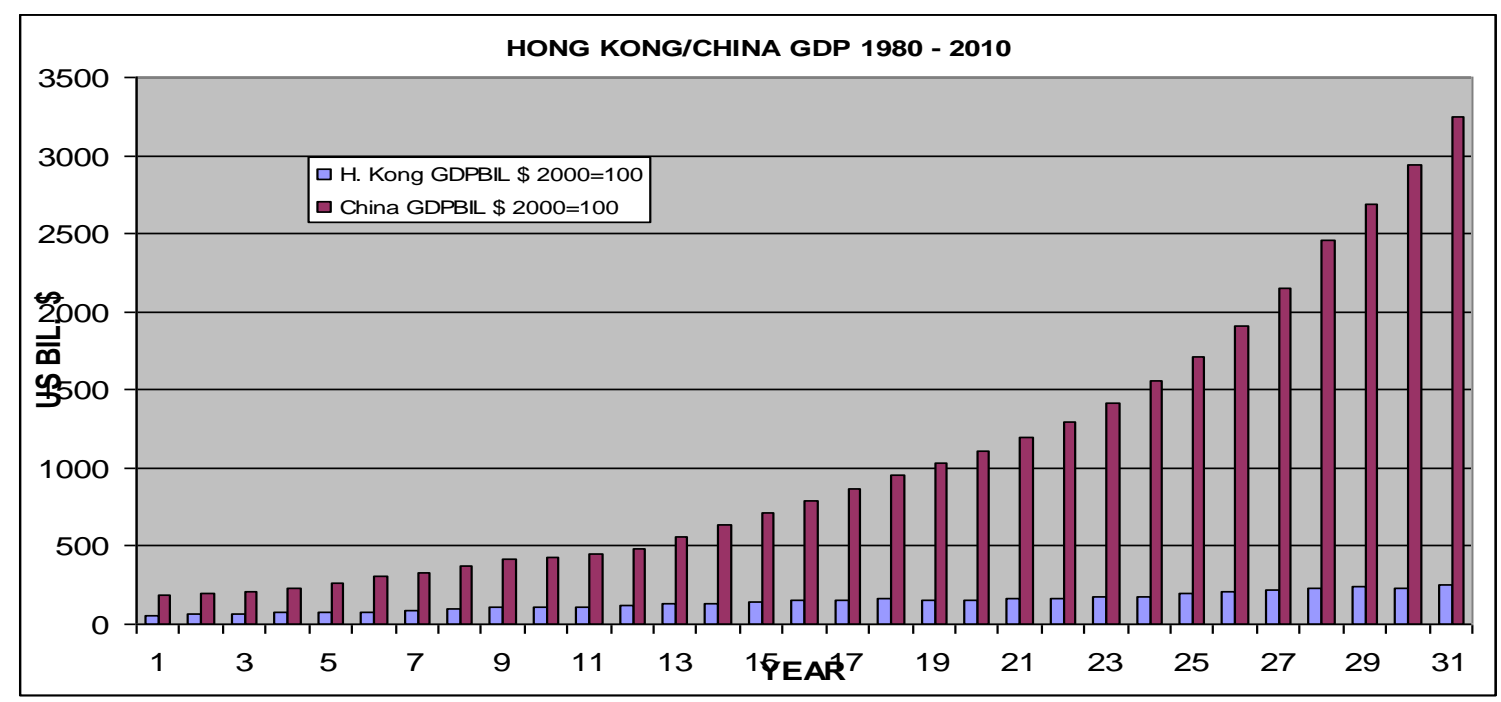

Figure 2

The figure above, Figure 2, shows the Gross Domestic Product for both countries, in 2000 US dollars. This figure shows almost the same economic picture as the previous one, both countries growing, but in this case the GDP of China has more than tripled between 1997 and 2010. We believe that this needs more research in order to find out why there is so much increase in China's GDP, especially during a time when the rest of the world was in a serious economic turmoil. 
The next figure, Figure 3, shows the unemployment rates of both countries between 1980 and 2010. In Figure 3, as well as Table 1, we can see that both China and Hong Kong have fairly low unemployment rates for the most part, with the exception of Hong Kong during 2002 and 2003 when their unemployment went over 7\%, but came back down again relatively fast. The conclusion we derive here is that unemployment is not a major problem for either one of these countries.

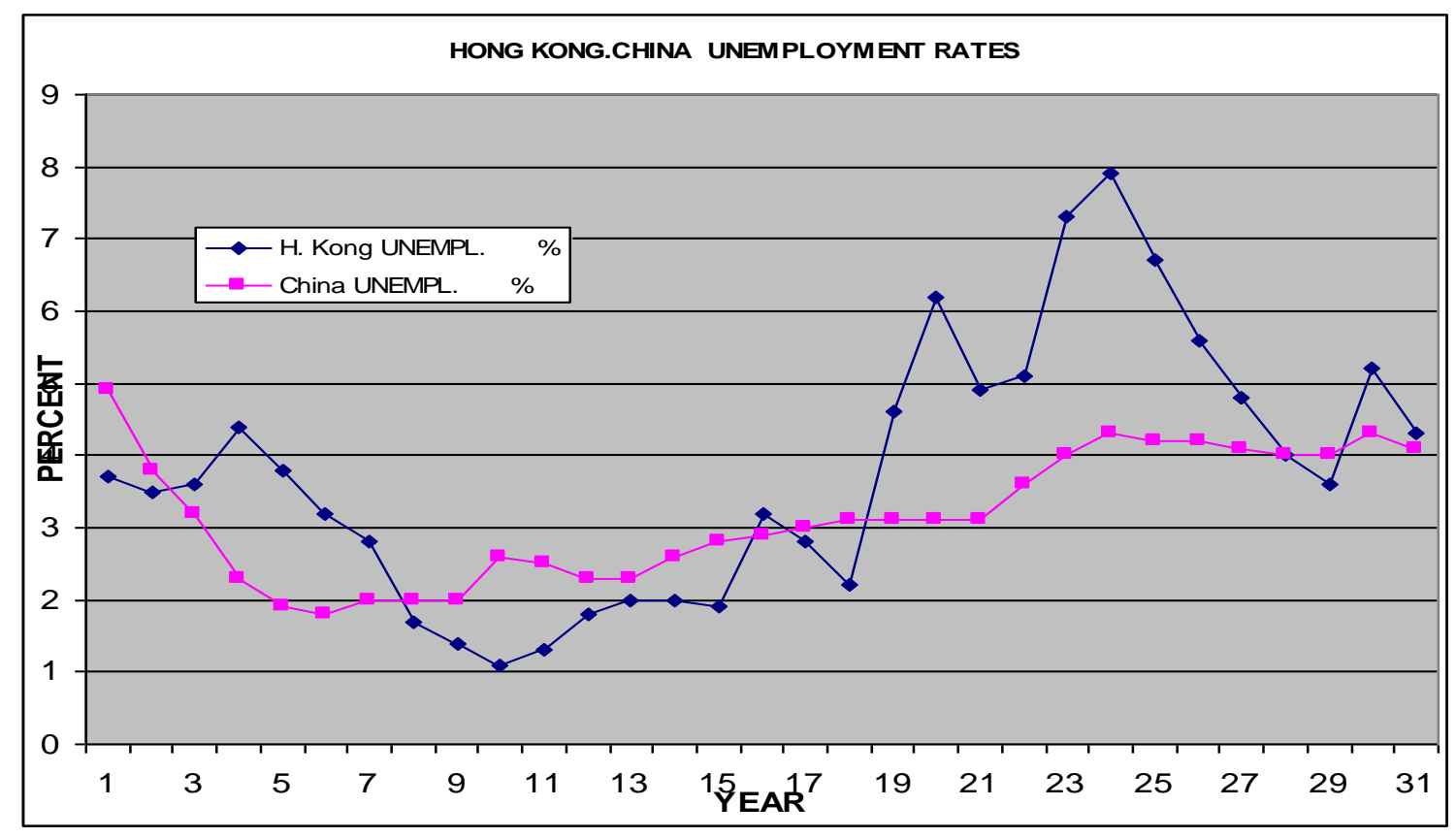

Figure 3

The next table, Table 2, shows the Inflation Rates for both countries as well as their Growth Rates. Both indicators will be shown in the figures that follow and will be discussed.

Table 2: Hong Kong and China Data 1980 - 2010

\begin{tabular}{|c|c|c|c|c|}
\hline & H. Kong & China & H. Kong & China \\
\hline YEAR & Infl. Rate & Infl. Rate & Gr. Rates & Gr. Rates \\
\hline & $\%$ & $\%$ & $\%$ & $\%$ \\
\hline 1980 & &.. & 10 & 8 \\
\hline 1981 & 14.6 &.. & 9 & 5 \\
\hline 1982 & 10.99686 & .. & 3 & 9 \\
\hline 1983 & 9.9070827 &. & 6 & 11 \\
\hline 1984 & 8.7323322 & .. & 10 & 15 \\
\hline 1985 & 3.6268741 & .. & 1 & 13 \\
\hline 1986 & 3.4999358 & .. & 11 & 9 \\
\hline 1987 & 5.5557369 & 7.22 & 13 & 12 \\
\hline 1988 & 8.0089976 & 18.7364 & 8 & 11 \\
\hline 1989 & 10.169663 & 18.333 & 2 & 4 \\
\hline 1990 & 10.192207 & 3.0583 & 4 & 4 \\
\hline 1991 & 11.343795 & 3.5436 & 6 & 9 \\
\hline 1992 & 9.5611932 & 6.3403 & 6 & 14 \\
\hline 1993 & 8.7266775 & 14.5833 & 6 & 14 \\
\hline 1994 & 8.815813 & 24.2371 & 6 & 13 \\
\hline 1995 & 9.0689412 & 16.8971 & 2 & 11 \\
\hline 1996 & 6.3192856 & 8.324 & 4 & 10 \\
\hline 1997 & 5.8394003 & 2.8068 & 5 & 9 \\
\hline
\end{tabular}


Table 2 cont.

\begin{tabular}{|l|c|c|c|c|}
\hline 1998 & 2.857191 & -0.8446 & -6 & 8 \\
\hline 1999 & -4.0229979 & -1.4079 & 3 & 8 \\
\hline 2000 & -3.6926602 & 0.2553 & 8 & 8 \\
\hline 2001 & -1.658027 & 0.7229 & 0 & 8 \\
\hline 2002 & -3.055805 & -0.7659 & 2 & 9 \\
\hline 2003 & -2.5000783 & 1.1559 & 3 & 10 \\
\hline 2004 & -0.4458797 & 3.8842 & 8 & 10 \\
\hline 2005 & 0.8958543 & 1.8216 & 7 & 11 \\
\hline 2006 & 2.1088 & 1.4632 & 7 & 13 \\
\hline 2007 & 1.9564425 & 4.7503 & 6 & 14 \\
\hline 2008 & 4.2644792 & 5.8644 & 2 & 10 \\
\hline 2009 & 0.6134721 & -0.7029 & -3 & 9 \\
\hline 2010 & 2.3373805 & 3.3145 & 2 & 7 \\
\hline
\end{tabular}

Source: Inflation from the International Monetary Fund, International Financial Statistics and data files. Growth Rates from the World Bank national accounts data, and OECD National Accounts data files

Figure 4 shows the Inflation Rates, and it seems that since the two countries were united, inflation has not been a problem, although both countries had years of deflation, which is not necessarily good either. If we go a few years back though, around 1988 to around 1991 both countries had years of double digit inflation.

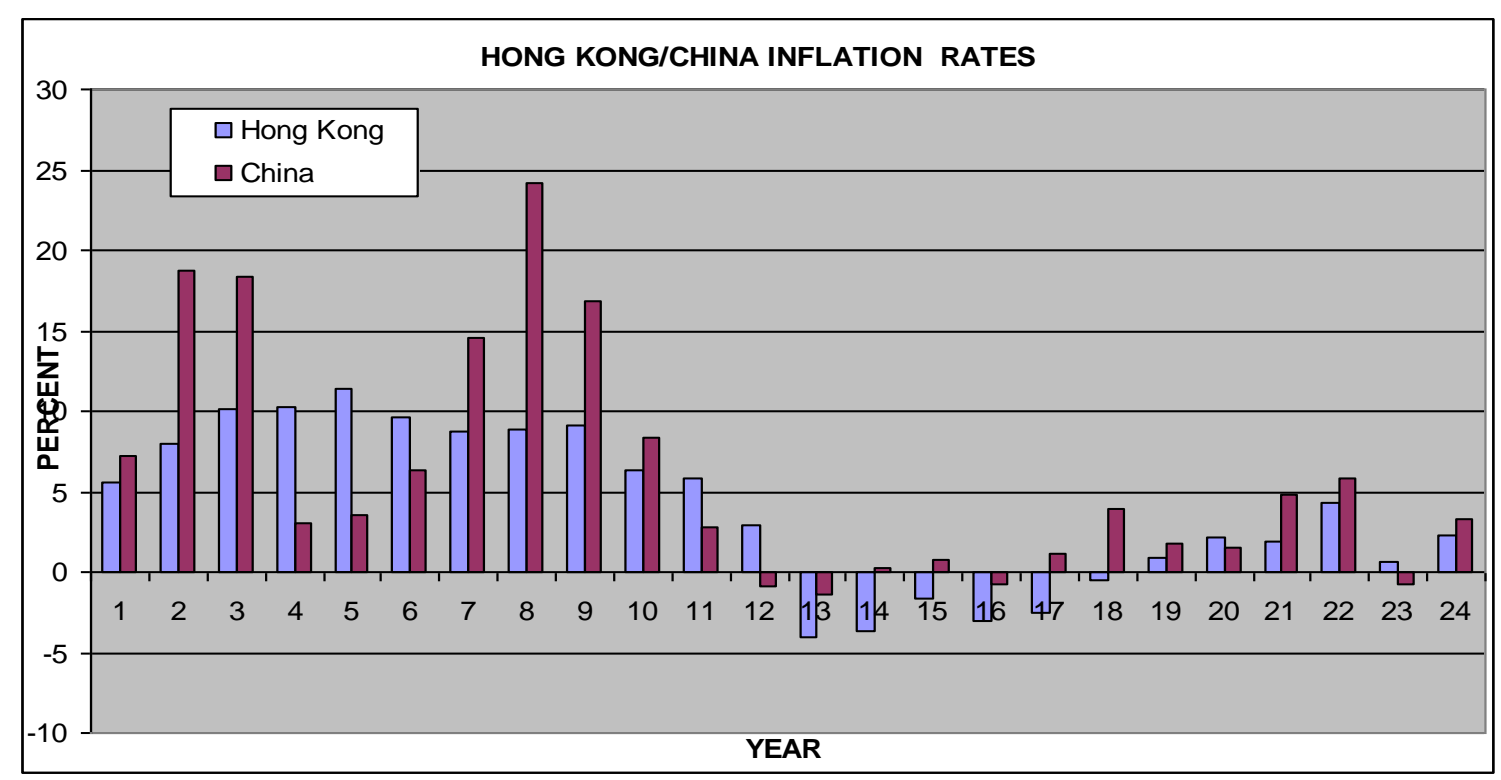

Figure 4 


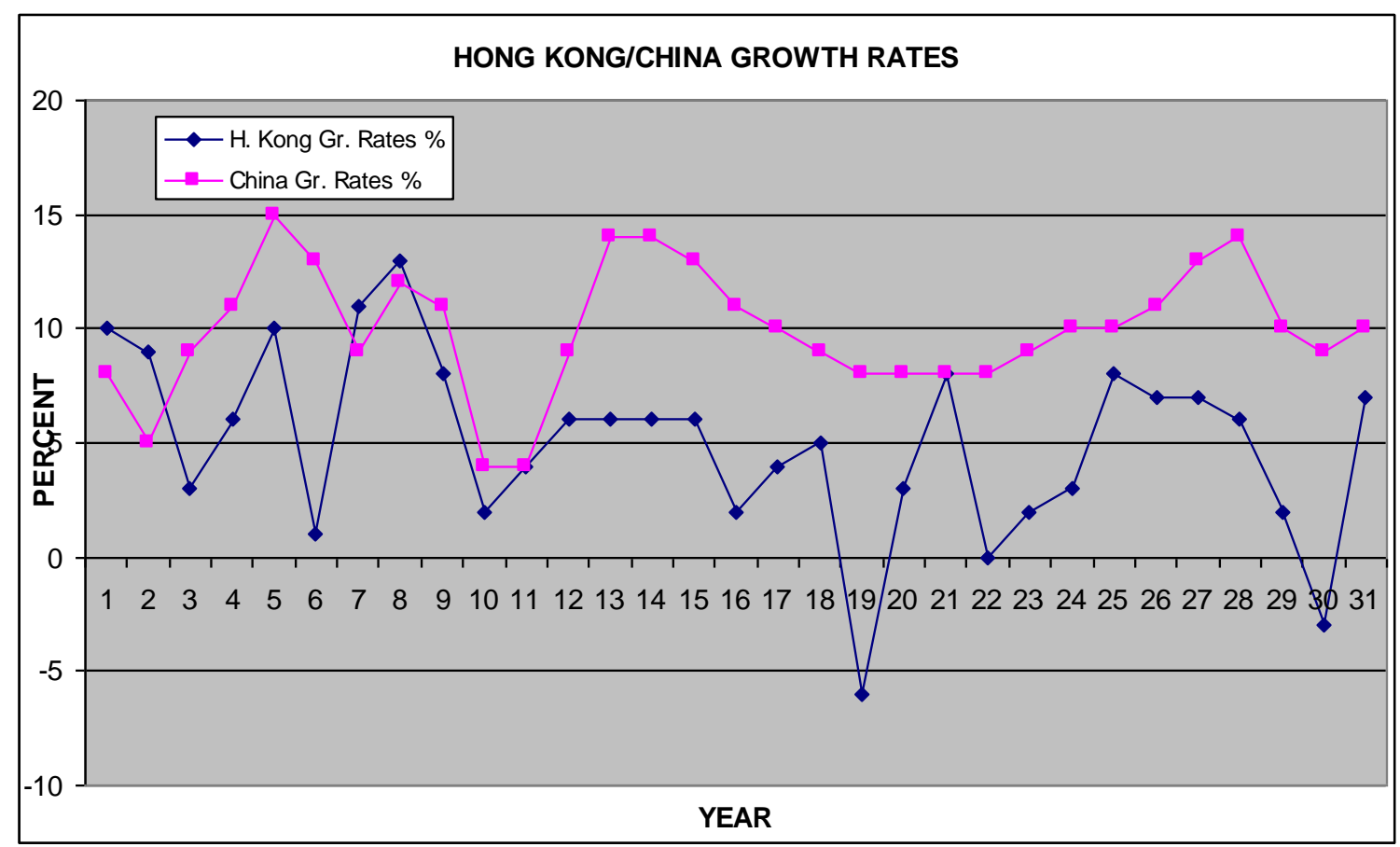

Figure 5

In this last figure, we show the Growth Rates, and although for Hong Kong the Growth rate has been very volatile, for the most part both countries have good Growth rates that range between 8 and 10 percent for the last 5 or 6 years with only one year, 2009, when Hong Kong had a negative rate.

\section{CONCLUSION}

The conclusion is intended to put everything discussed in the previous three sections together, and summarize the findings. Also, based on these findings some recommendations and suggestions will be made for the further development of the new union, as well as an attempt will be made to forecast the future.

In the two tables included in this paper, we presented some of the most important indicators about China and Hong Kong, and these indicators helped us in drawing some conclusions. Table 1 included the net exports for both countries, the GDP in US billions of dollars, and the unemployment rates for both of them since 1980. This is a good number of years for both before the return of Hong Kong to China, as well as after. The net trade data shows that prior to 1997 Hong Kong had 3 years of trade deficit and after 1997 it had only 2. Also Since 1997 Hong Kong was able to increase its trade surplus by more than 5 times. On the other hand China all in all had 2 years of trade deficit and both of them were before 1997. In fact it was able to increase its surplus by more than 30 times. This data seems to indicate that both of these countries play a very important role in the international arena, and they should take advantage of their trading abilities. The next set of data shows the GDP of both countries, and this data shows that both countries have very solid economies since their GDP has been steadily rising since 1997.

Table 2 shows the inflation rates for both countries, and the growth rates for both countries. Even though both of them had some high rates of inflation before 1997, it seems that after 1997 inflation is not a problem for either one of them since for both of them it is in very low single digits. Finally the growth rates shown in Table 2 also support what we stated earlier that both countries have very strong economies, since they both have strong growth rates and rising, especially during the years when the rest of the world is in a serious economic turmoil.

Even though the reunification looks promising, we find different attitudes in both countries. In Hong Kong, we find people that are positive and optimistic, but we also find people that are negative and skeptical. People are optimistic for the following reasons: 
a. Hong Kong has a solid economic and financial structure and good management which ensures the continuous and steady growth.

b. $\quad 60 \%$ of foreign direct investment into China, either comes from or through Hong Kong, so that the Chinese government will not do anything to jeopardize this.

On the other hand, people are skeptical for their own reasons:

a. They are afraid that the Chinese government will interfere in the daily operations of Hong Kong, and this will destroy the free market system.

b. They are afraid that more and more Hong Kong residents will choose to relocate to other countries, and this will depress the real estate market.

c. They are afraid that due to the threat of a communist system foreign investments will drop dramatically.

The attitude in China though, is much more optimistic that China will not go back to a centrally planned system, and the following are the reasons that support this:

a. $\quad$ No one in China advocates such a reversal.

b. Twenty years of reforms have created too many interests vested in the growth of the Chinese economy.

c. Taiwanization - in the long term they aim to duplicate in China, the political transformation that occurred in Taiwan.

Through all the research in the literature, it is the authors' opinion that even though the reunification was unavoidable, it is going to be beneficial to China and Hong Kong, as well as the region, but it depends mostly on what China decides to do. If they start interfering in Hong Kong and try to change the free market system, this could prove to be disastrous.

As mentioned above, this paper is not complete, and we plan to do more work in order to find more solid conclusions. To this end, any suggestions are welcome.

\section{AUTHOR INFORMATION}

Pete Mavrokordatos is a professor of Economics at Tarrant County College, where he is teaching Prin. of Economics. He is also teaching Economics both graduate and undergraduate at the University of Phoenix, as well as The Intercollege Larnaca campus, Cyprus. His research concentration is International Trade and Finance as well as International Economics and Macroeconomics. E-mail: e.mavrokordatos@ @tccd.edu (Corresponding author)

Stan Stascinsky is a professor of Mathematics and Statistics at Tarrant County College, where he is teaching several courses of Math and Statistics. Stan also teaches from time to time at the University of North Texas as an adjunct. His research concentration is Statistical analysis. E-mail: stanley.stascinsky@tccd.edu

\section{REFERENCES}

1. China - A General Survey, Qi Wen, Foreign Languages Press, $2^{\text {nd }}$ Edition, 1981.

2. Emerging China, edited by Thomas Draper, Volume 52, Number 1, The H.W.Wilson Company, New York, 1980.

3. "Emerging Market Indicators: Economy", Anonymous, The Economist, February 21, 1998, Vol. 346, p.110.

4. Estimates of Gross Domestic Product, 1961 - 1996, Census and Statistics Department, Hong Kong, March 1997.

5. "Hong Kong Ushers in a New Era", Published by New Star Publishers, Beijing, People's Republic of China.

6. Quarterly Report of Gross Domestic Product Estimates, Second Quarter 1997, Census and Statistics Department, Hong Kong, November 1997. 
7. Understanding China, A Guide to China's Economy, History and Political Structure, John Bryan Starr, Hill and Wang, New York, 1997.

8. http://www.treasury.boi.ie/country/hongkong.html

9. http://www.globalfindata.com

10. http://www.info.gov.hk/c

11. http://www.thedora.com/hon_kong_economy.html

12. $\quad$ http://www.odci.gov/cia/publications/nsolo/factbook/ch/htm

13. http://www.odci.gov/cia/publications/nsolo/factbook/hk.htm

14. http://www.tdc.org.hk/main/economic.htm

15. http://asiarisk.com/hk.html\#300

16. http://asiarisk.com/china.html\#300

17. $\quad$ http://www.fenbd.com/cor/fccm/research/html/china101697.htm 